\title{
Over twenty years trend of chloride ion concentration in Lake Biwa
}

\author{
Yasuaki AOTA*, Michio KUMAGAI ${ }^{1)}$ and Kanako ISHIKAWA ${ }^{2)}$ \\ Institute of Nature and Environmental Technology, Kanazawa University, Kakuma, Kanazawa 920-1192, Japan \\ ${ }^{1)}$ Lake Biwa Research Institute, Uchidehama, Otsu, Shiga 520-0806, Japan \\ ${ }^{2)}$ Division of Applied Biosciences, Graduate School of Agriculture, Kyoto University, Kyoto 606-8502, Japan \\ *e-mail corresponding author: yaota@kenroku.kanazawa-u.ac.jp
}

\begin{abstract}
Recent increase of chloride ion concentration in Lake Biwa was considered. Over the past 20 years' data at the North Basin of Lake Biwa showed that chloride ion concentration has been continuously increasing from 7.4 to $9.9 \mathrm{mg} \mathrm{l}^{-1}$ at $0.5 \mathrm{~m}$ depth from lake surface and from 7.3 to $9.9 \mathrm{mg} \mathrm{l}^{-1}$ above the bottom (depth of over $80 \mathrm{~m}$ from lake surface). This low level salinity indicated, however, about 35\% increase through 20 years. In this paper, we reported the trend and the tendency of chloride ion concentration at some locations and the change of climatic data through 20 years in Lake Biwa. In a short period within one year, chloride ion concentration clearly fluctuated in the upper water layer. This fluctuation was mostly influenced by precipitation. Similar trend of chloride ion concentration could be seen in the South Basin of Lake Biwa with much higher concentration than that in the North Basin. We also discussed the long-term changes of chloride concentrations in 5 major rivers with large catchment area, water level and precipitation. The data of river discharge indicated that some rivers in the southern part of the North Basin in Lake Biwa contain a relatively high chloride concentration compared with others. Furthermore, we proposed a simple conceptual model with variable outflow and inflow fluxes. This conceptual model expressed an amount of chloride budget. We estimated the average chloride flux flowing from the watershed into Lake Biwa using the data of chloride ion concentration in the lake and the data of water discharge from the lake. Comparing the results of the model analysis with the data of 12 major rivers contributing large flux to Lake Biwa, we suggested that river inflow is one of the major sources to induce the increase of chloride ion concentration in the lake, and the inflow from non-point source can be also important sources.
\end{abstract}

Key words: Lake Biwa, chloride, salinity, precipitation, water level, river

\section{INTRODUCTION}

Lake Biwa is the largest (surface area of $670 \mathrm{~km}^{2}$, average volume of $27.5 \mathrm{~km}^{3}$ ) and the most ancient (nearly 5Ma) inland lake in Japan. The lake is located in Shiga Prefecture, Japan, which is near Kyoto and Osaka Prefectures, and is divided into two basins by the Biwako-Ohashi bridge (Fig. 1). The outflow from Lake Biwa is the Seta River only (Fig. 1), and the amount of discharge is well controlled by the water gate called Arai-Zeki. There are 120 rivers flowing into Lake Biwa. Because of the large freshwater body and the geographical location near Kyoto - Osaka area, Lake Biwa is one of the most important water resources for drinking, agricultural, pleasure, fishery and industrial use.

The increase of lake salinity is one of serious concerns, because a lake sustains safety water required for human being life and/or richness of biota. For example, Aral Sea in Central Asia, which is the closed inland lake and used to have the $4^{\text {th }}$ area in the world (about 100 times of Lake Biwa), is now exposed to the serious threats of loosing water body and rising salinity level. The increase of salinity was from 10 to $>30 \mathrm{~g} \mathrm{l}^{-1}$ between 1960 and 1991 in the lake (e.g., Williams 2001), and brought serious influences such as a destruction of the birds or wildlife ecosystem, collapse of fishery, and damage of human health (Williams \& Aladin 1991). In
Pyramid Lake, USA, which has 0.67 times of area and almost same volume as Lake Biwa, salinity level changed from 3.75 to $5.5 \mathrm{~g} \mathrm{l}^{-1}$ between 1933 and 1980 (Williams 2001).

In case of Lake Biwa, salinity level is quite lower (from 7.4 to $9.9 \mathrm{mg}^{-1}$ at $0.5 \mathrm{~m}$ from lake surface and from 7.3 to $9.9 \mathrm{mg} \mathrm{l}^{-1}$ above the lake bottom) than those of the salt lakes mentioned above. However, it increased about 35\% linearly above the lake bottom during last 20 years (Fig. 2) even if it fluctuated from 1978 to 1980 . In this paper, we reported the monthly trend of chloride ion concentrations in the North Basin of Lake Biwa. Also, we analyzed monthly change of water level, precipitation, chloride ion concentration of the South Basin and the rivers flowing into Lake Biwa with top 5 catchment areas through 20 years.

When we estimate or predict the present and/or the future lake salinity, calculation of the water budget is essential. In Lake Biwa, water outflows to Seta River, Uji hydroelectric power station and the canal of KyotoSosui, and all discharge rates are well monitored. However, the effects of the inflows to Lake Biwa are very complicated because different water flows such as rivers flowing into the lake, groundwater, agricultural or industrial drain water, or surface water due to heavy rainfall or flood containing various chemical materials, and most of them were not measured well for analysis. To 


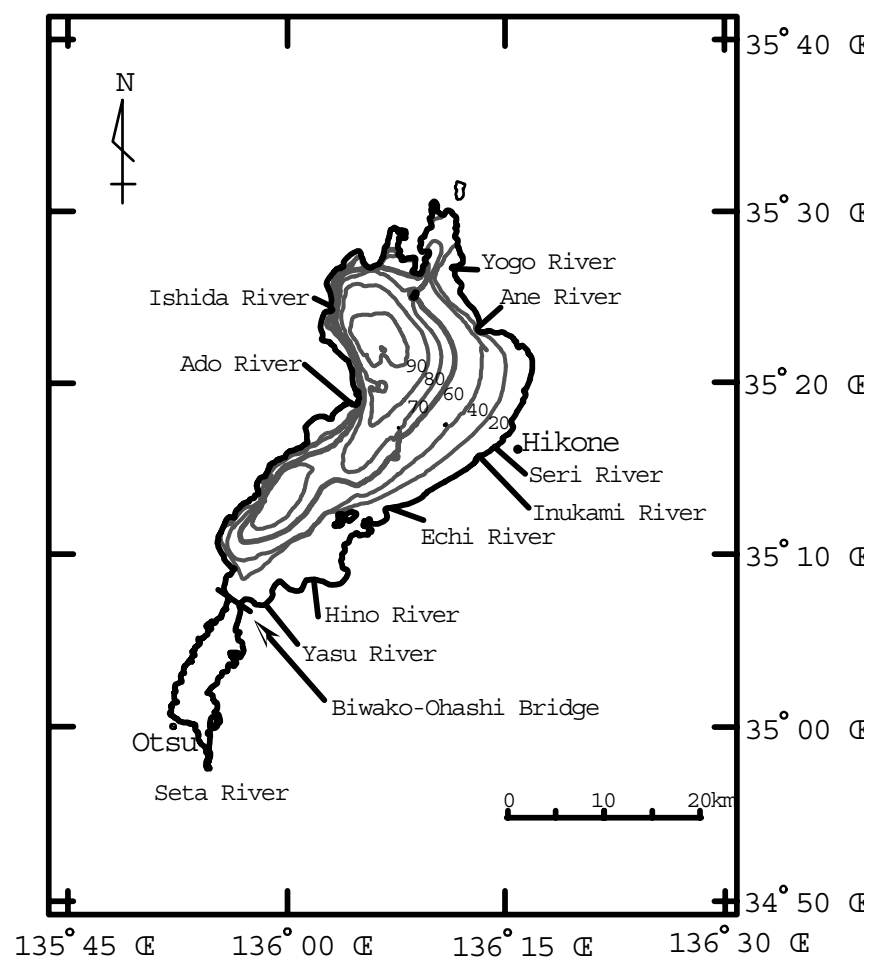

Fig. 1. Map of Lake Biwa.

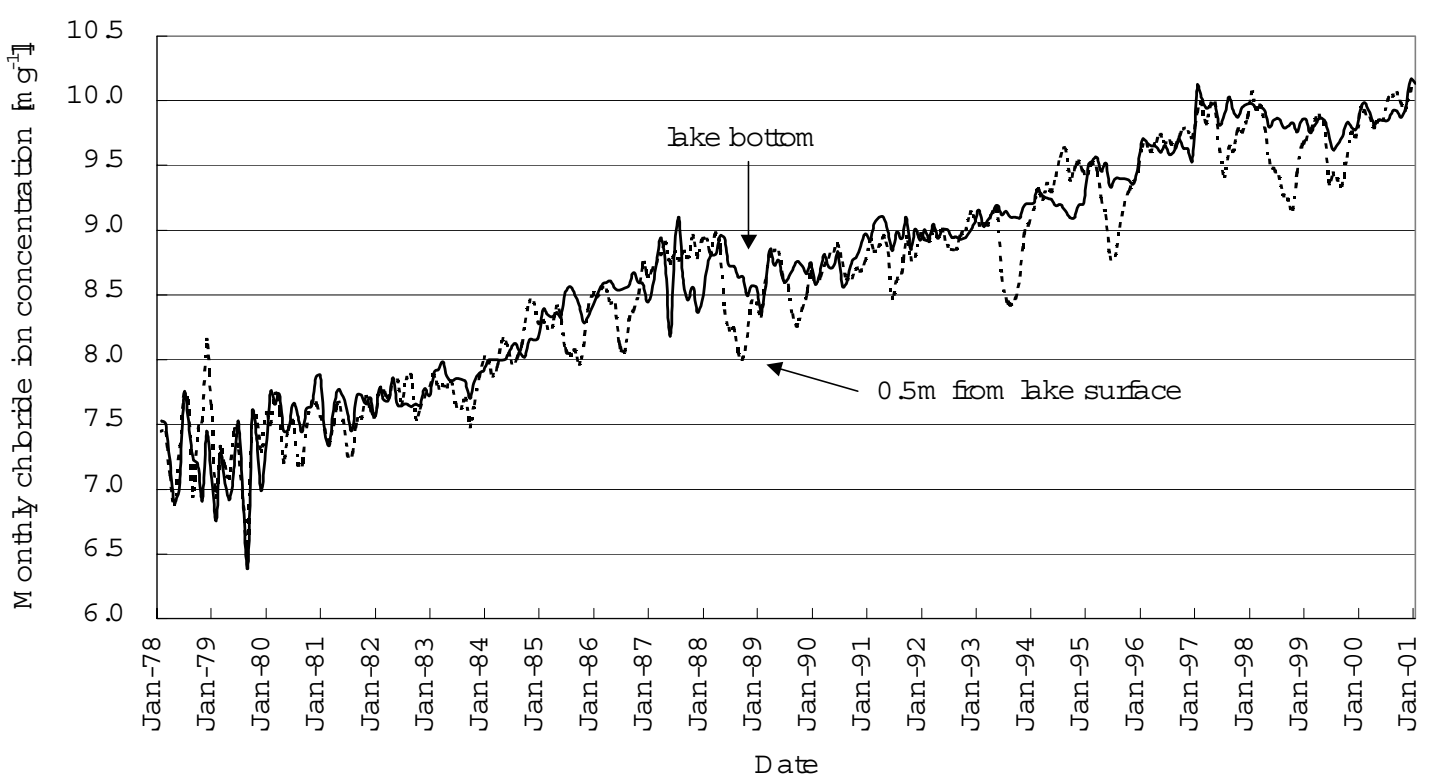

Fig. 2. Monthly concentration of chloride ion in the upper and bottom layers at the deepest point in Lake Biwa.

understand the rising processes of the chloride ion concentration, we considered some causes, and we proposed a conceptual model approach.

In the following section, we explain the procedure of our model approach. Then, we discuss the trends of chloride ion concentration and the climate in order to clarify the processes that sustain the increase of the chloride ion concentration of Lake Biwa, and show the result of our conceptual model. All observed data were collected and arranged from "Kankyo Hakusyo" which are the environmental white papers published by Shiga Prefecture, and from "Shigaken Kisyo Geppo" which are monthly weather report papers published by Japan Weather Association. 


\section{CONCEPTUAL MODEL APPROACH}

The water in Lake Biwa flows basically from the North to the South Basin. Water discharge from the lake is well controlled by the gate, but the estimation of the water budget in the lake is very difficult because of having complex sources of water inflows to the lake. Let us put the average chloride ion concentration of inflows to the lake as $C_{R}$, and the total amount of inflows as $Q_{R}$. Assuming that the lake volume is constant, then the dynamics of the chloride flux is represented by:

$$
\begin{gathered}
V_{N} \frac{d C_{N}(t)}{d t}=-C_{N}(t) Q_{\text {in }}(t)+C_{R}(t) Q_{R}(t), \\
V_{S} \frac{d C_{S}(t)}{d t}=C_{N}(t) Q_{\text {in }}(t)-C_{S}(t) Q_{\text {out }}(t),
\end{gathered}
$$

where $V_{N}$ and $V_{S}$ are the volume of the North Basin and South Basin of Lake Biwa, and $C_{N}$ and $C_{S}$ are the concentrations of chloride ion in the North Basin and South Basin of the lake, respectively. Variables $Q_{\text {in }}$ and $Q_{\text {out }}$ are the amount of flow from the North Basin to the South Basin of the lake and the discharge from the South Basin of the lake, respectively. From the observation data, we assume that the concentrations of chloride ion in the North and the South Basins change as exponential functions:

$$
\begin{aligned}
& C_{N} \approx \alpha_{N} \exp \left(\beta_{N} t\right), \\
& C_{S} \approx \alpha_{S} \exp \left(\beta_{S} t\right),
\end{aligned}
$$

where $\alpha_{N}, \beta_{N}, \alpha_{S}$ and $\beta_{S}$ are constant, which are determined by the field data of the chloride ion concentrations. With the assumption and the above equations, the chloride flux $C_{R} Q_{R}$ can be expressed by:

$$
\begin{aligned}
& C_{R}(t) Q_{R}(t) \approx V_{N} \alpha_{N} \beta_{N} \exp \left(\beta_{N} t\right)+ \\
& +V_{S} \alpha_{S} \beta_{S} \exp \left(\beta_{S} t\right)+\alpha_{S} \exp \left(\beta_{S} t\right) Q_{\text {out }}(t)
\end{aligned}
$$

\section{RESULTS AND DISCUSSION}

Figure 2 shows the monthly change of chloride ion concentrations at $0.5 \mathrm{~m}$ depth from lake surface and $1 \mathrm{~m}$ height above the lake bottom (over $80 \mathrm{~m}$ of depth from lake surface) near the deepest point in the North Basin of Lake Biwa. As seen in figure 2, trends of chloride ion concentrations near the surface and the bottom showed similar change from February 1978 to June $1985\left(\mathrm{r}^{2}=\right.$ $0.68, \mathrm{n}=2693, \mathrm{p}<0.001)$. After June 1985, the difference between both concentrations expanded, and the period with big differences of the concentration became longer than that of the previous period (Fig. 3). Similar tendency as the difference could be seen in the monthly change of water level (Fig. 4). Water level has not fluctuated much until 1985. However, since 1985, the period of low water level has become prolonged.
The concentration of chloride ion contained in the rain is almost less than $2 \mathrm{mg} \mathrm{l}^{-1}$ in the region of Lake Biwa (Tanaka \& Ichiki 1986). Therefore, the rain falling directly to the lake tends to dilute the chloride ion concentration in the lake. Figure 5 shows monthly precipitation at Hikone (see Fig. 1). In 1994, due to relatively low rainfall compared with an average year (Fig. 5), one of the lowest water levels during the observation period was recorded (Hori et al. 1996). From 1993 to 1995 , difference of chloride concentrations between bottom and upper layers changed dramatically (Fig. 3) with the amount of rainfall. In heavy rainy year of 1993 and 1995, the chloride ion concentration at surface decreased largely, and it increased in dry year of 1994, respectively (Fig. 6a). Similar relationship between precipitation and chloride concentration can be seen in 1987-1989 (Fig. 6b). Therefore, the dilution due to the rain falling directly on the lake may be one of the key factors causing great fluctuation of the chloride ion concentration in the upper layer.

Figure 7 shows annual average chloride ion concentrations of the rivers with large catchment area: Yasu River with $383.8 \mathrm{~km}^{2}$, Ane River with 369.8 $\mathrm{km}^{2}$, Ado River with $306.9 \mathrm{~km}^{2}$, Hino River with $210.9 \mathrm{~km}^{2}$, Echi River with $202.8 \mathrm{~km}^{2}$ of the catchment area, respectively (Oonishi 1986). These rivers are the five big rivers with large catchment area flowing into Lake Biwa, and the sum of the catchment areas of the five rivers covers about $47 \%$ of whole catchment area in Lake Biwa (Oonishi 1986). Each average chloride ion concentration is derived by:

$$
\sum_{i} C_{i} Q_{i} / \sum_{i} Q_{i}
$$

where $C_{i}$ is the chloride ion concentration, $Q_{i}$ is the discharge from each river, and subscript $i$ denotes month in a year. In figure 7, chloride concentrations of Yasu River and Hino River exceed the maximum level of Lake Biwa average data over most of the periods. This suggests that the high chloride might be supplied from two rivers. However, in order to know the contribution of each river to the chloride ion concentration level of the lake, the estimation of chloride flux is needed.

As one of the approaches to estimate chloride flux with complex input sources, we proposed conceptual model approach. Figure 8 shows annual changes of chloride flux in the inflows estimated from equation (1 and of the total chloride flux from 12 rivers flowing into Lake Biwa. In equation (1, we set the volume of the North Basin and the South Basin, $V_{N}$ and $V_{S}$, as 27.3 $\mathrm{km}^{3}$ and $0.2 \mathrm{~km}^{3}$, respectively. The outflow Qout was taken as the sum of annual water discharges from Seta River, Uji hydroelectric power station and Kyoto channel. Parameters $\alpha_{N}, \beta_{N}, \alpha_{S}$ and $\beta_{S}$ were taken as 7.6191, $0.0126,8.2217$ and 0.0131 , respectively. 


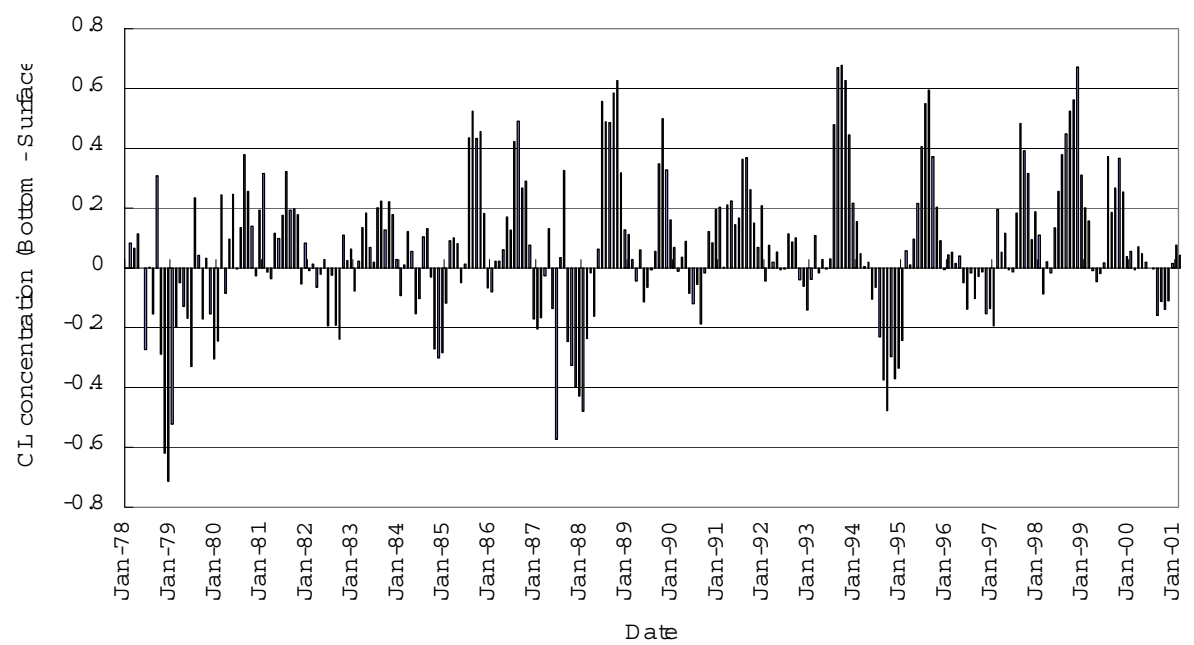

Fig. 3. Monthly change of the differences between bottom and upper chloride ion concentration.

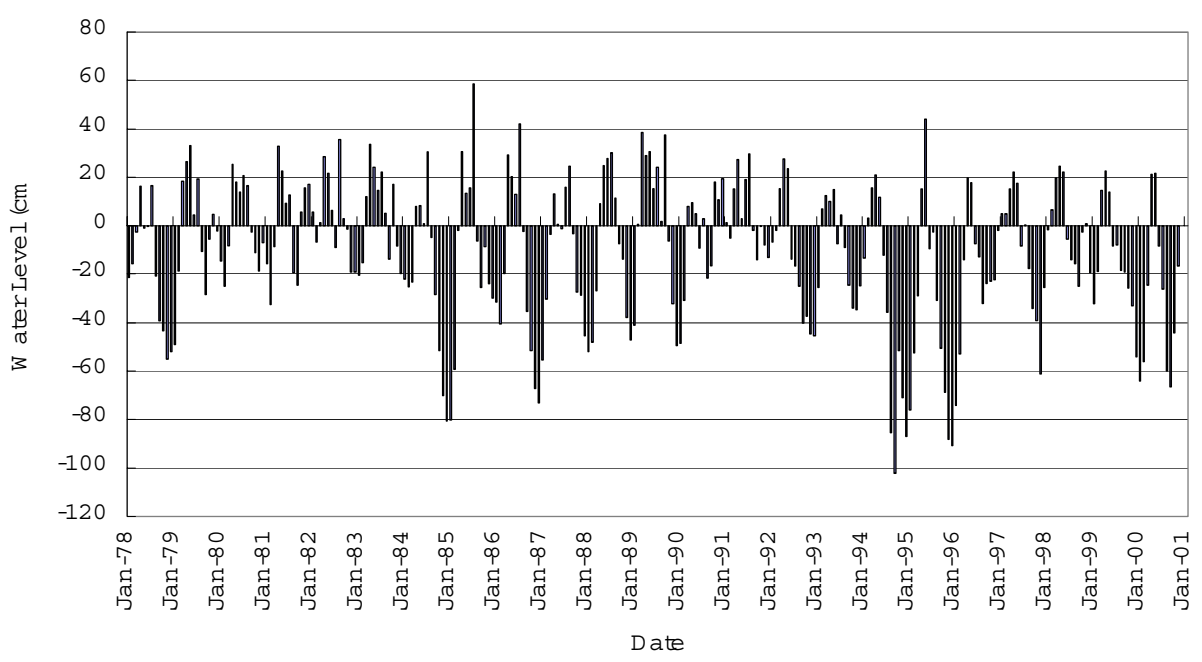

Fig. 4. Monthly water level change.

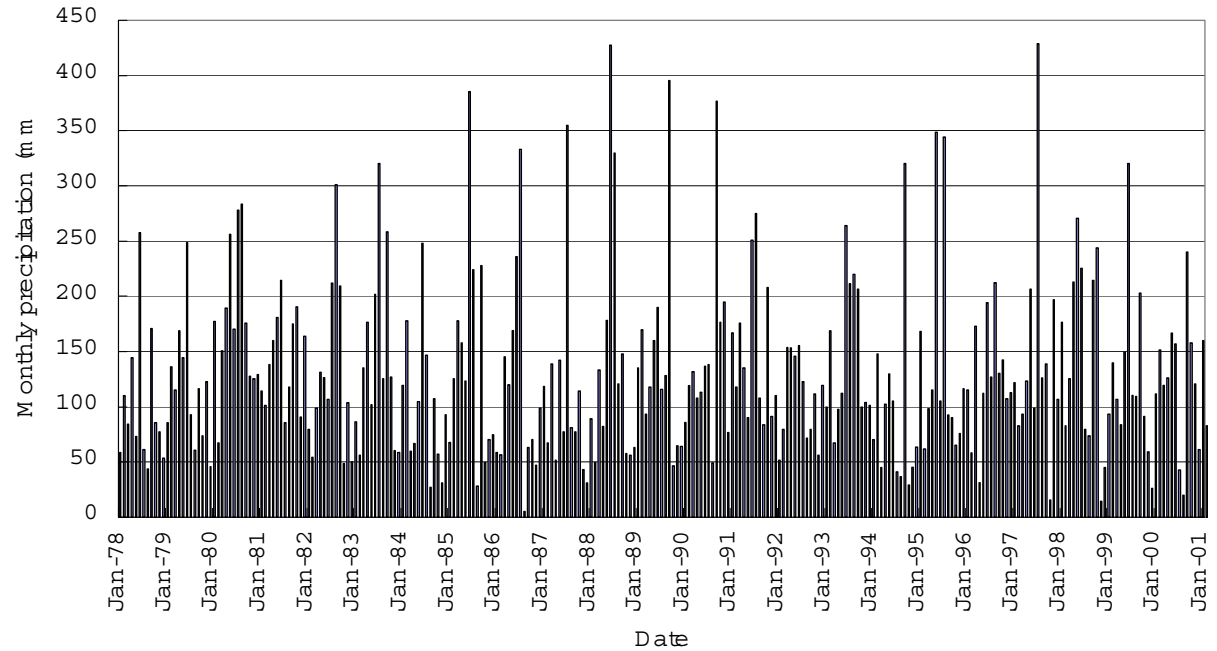

Fig. 5. Monthly precipitation change. 

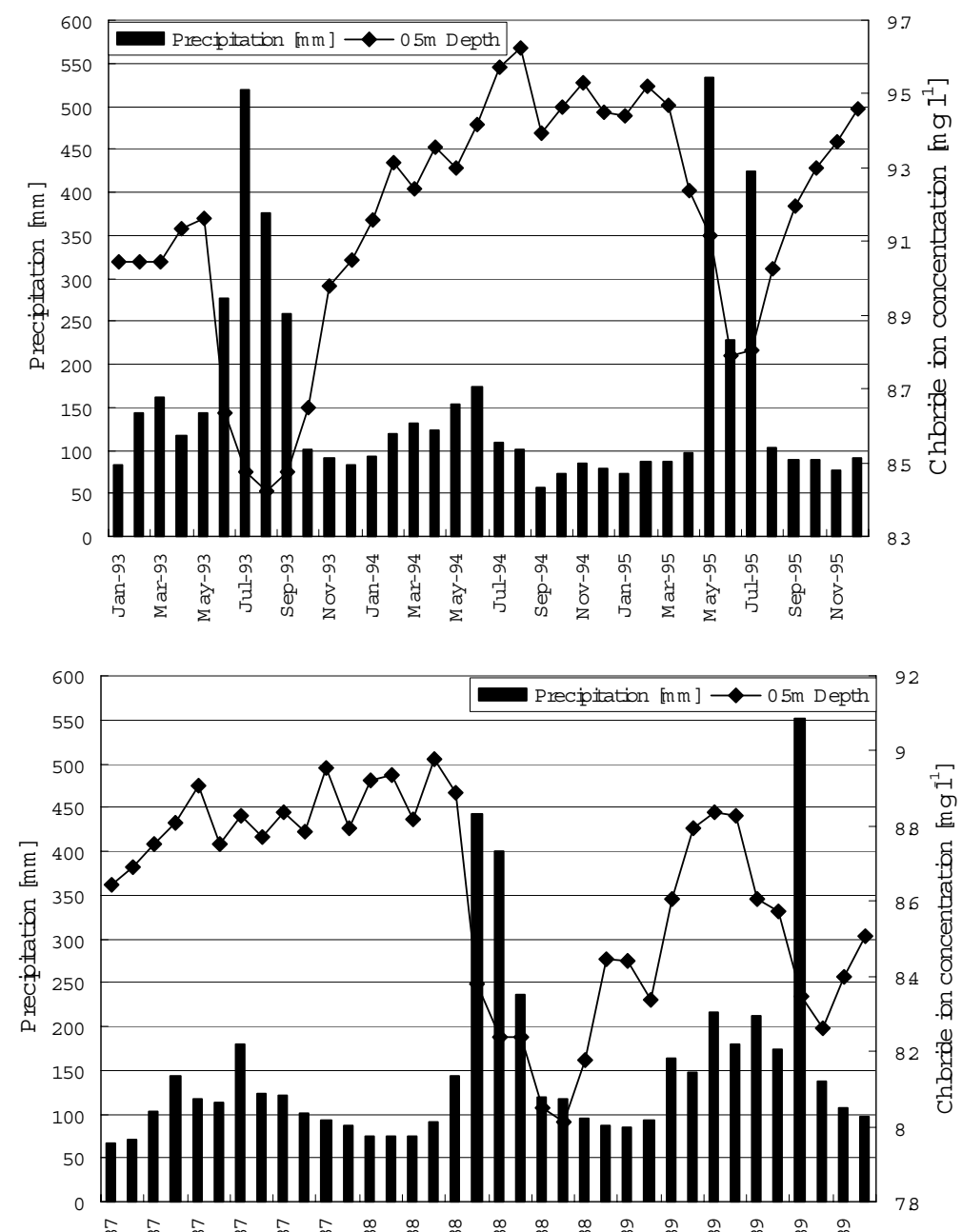

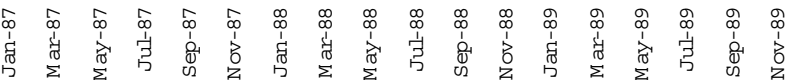

Fig. 6. Monthly concentration of chloride ion at $0.5 \mathrm{~m}$ of depth and precipitation in 1993-1995 (upper) and in 1987-1989 (lower).

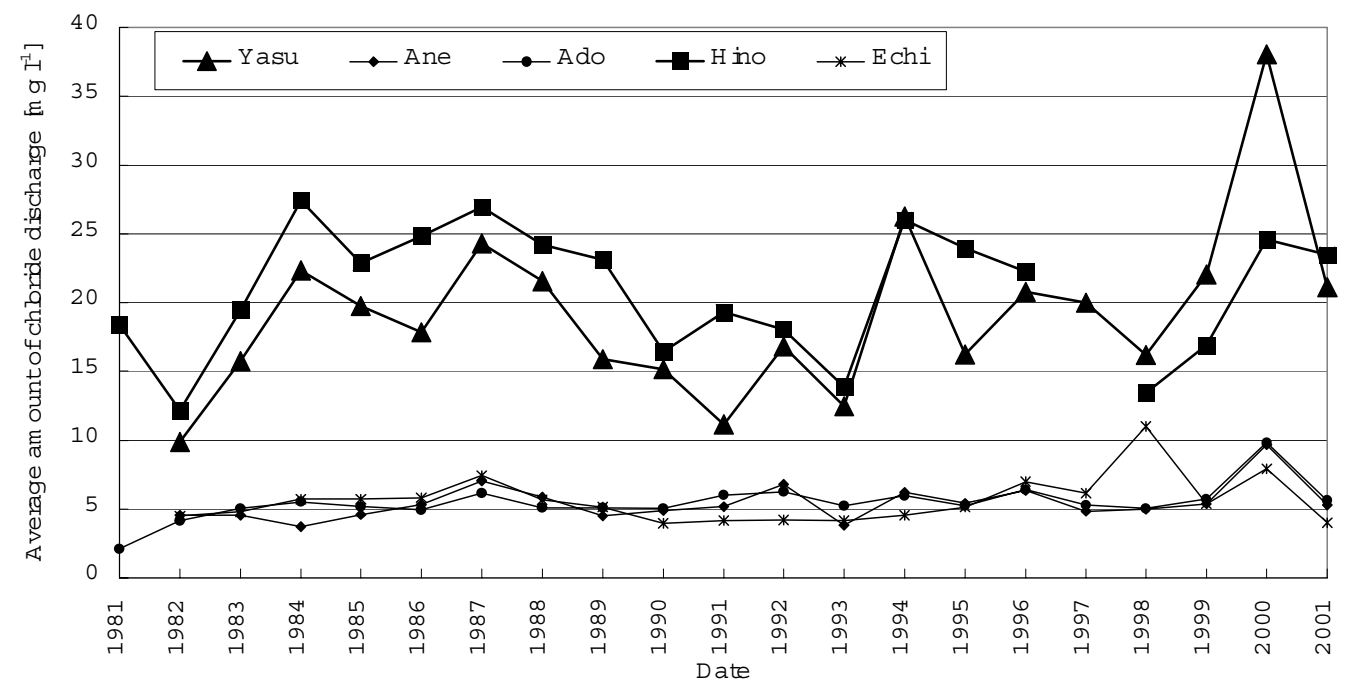

Fig. 7. Annual change in average amount of chloride discharge from rivers. 


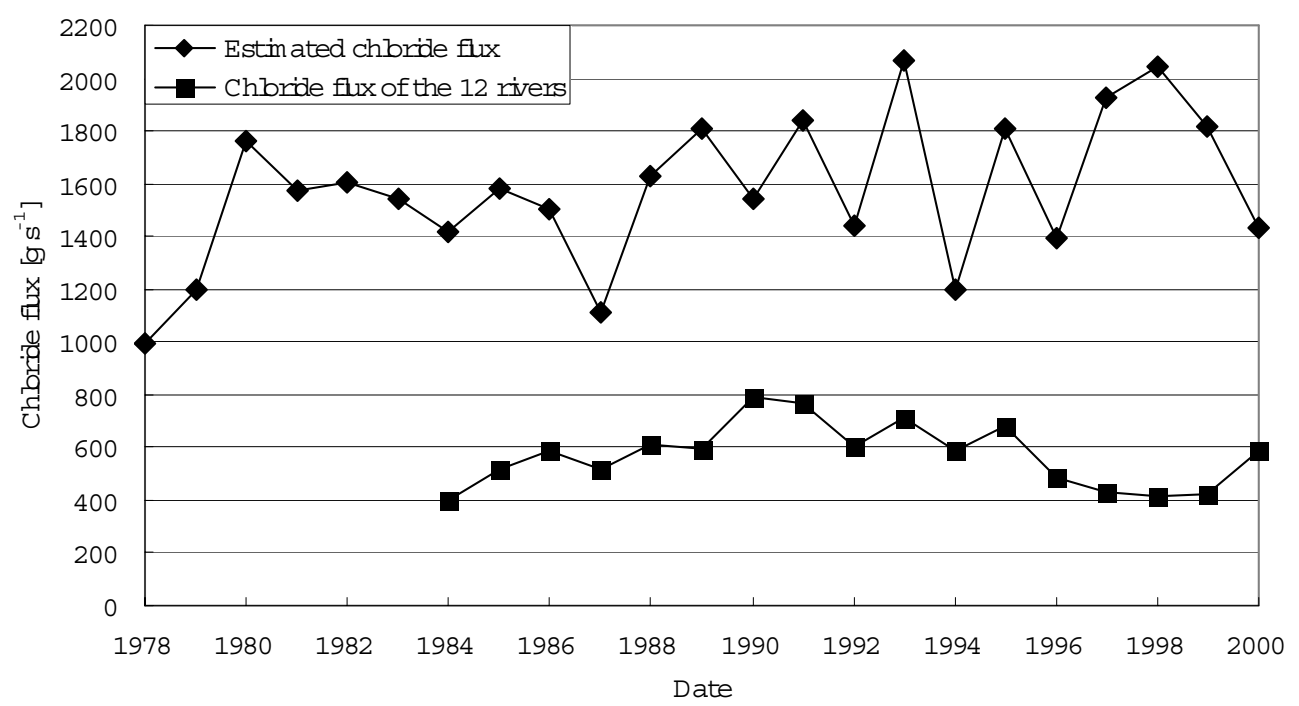

Fig. 8. Annual change in estimated chloride inflow and in total chloride flux from 12 rivers.

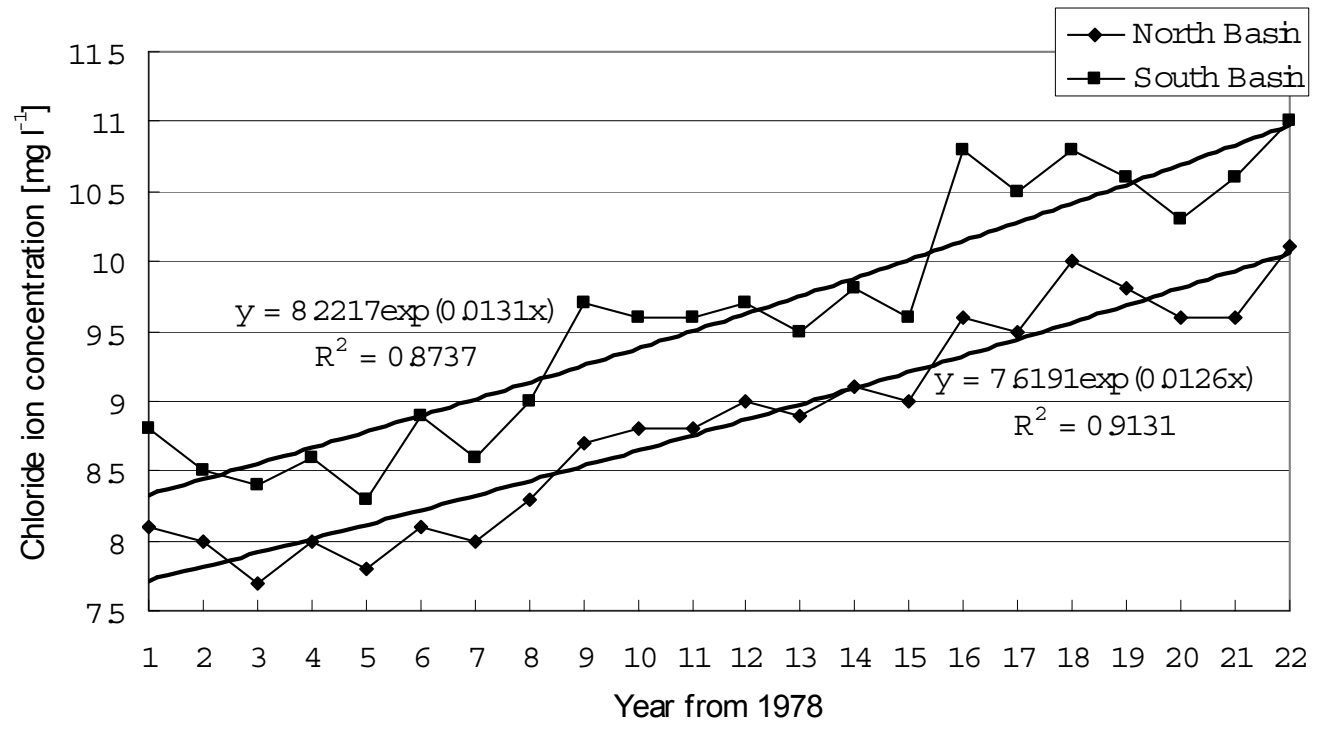

Fig. 9. Annual change of chloride ion concentration in the North Basin and the South Basin of Lake Biwa.

These parameters were determined from a regression analysis of annual changes of the chloride ion concentration in the North and South Basin of Lake Biwa $\left(r^{2}=0.9131\right.$ in the North Basin and 0.8737 in the South Basin of the lake, see Fig. 9). Calculation was started from $1978(\mathrm{t}=0)$. Note that we assumed many parameters as constant. Therefore, this simple model is quite conceptual. In figure 8 , the sum of the annual water flux of these twelve rivers covers about $90 \%$ of reported data. Unfortunately, the data before 1984 was not sufficient to compare with chloride flux estimated from equation ( 1 .

In figure 8 , the demand of chloride inflow to sustain the chloride ion concentration in the lake was always greater than chloride inflow from twelve rivers. Average demand of the chloride inflow during calculation period in our model was about three times of the inflow from the rivers. However, river's data reported here might be underestimated for the real water flux, because it is difficult to detect the large flux in a short-term such as flood due to heavy rain in the field. Therefore, the actual contribution of river flux may be greater than that of the river flux estimated from the measured data. Furthermore, average chloride inflow estimated by the model analysis includes the content of whole chloride inflow from the lake watershed. For example, inflow from land surface due to heavy rain and/or flood and inflow through drain water have not been evaluated. Therefore, 
this result may show underestimated flux of inflow. Such unmeasured flux may take a large contribution to the concentration of the chloride ion in the lake.

It is well known that the lake water sometimes flow from the South Basin to the North Basin in Lake Biwa, although it flows from the North Basin to the South Basin on the average. Water flow from the South Basin to the North Basin can be caused by an intrusion of density currents, and by an excess transport due to oscillation of seiche and/or internal waves (Oonishi \& Imasato 1974). Therefore, as one of the possibilities for the increase of chloride ion concentration in the North Basin, we can suggest that the water exchanges between two basins may transport the high chloride ion concentration from the South Basin (Fig. 9) to the North Basin of the lake. In case of 2001, average chloride concentration was somewhat high (about $10.2 \mathrm{mg} \mathrm{l}^{-1}$ ) in southern part of the North Basin, and was low (about $10.0 \mathrm{mg} \mathrm{l}^{-1}$ ) near the center of the North Basin (Kankyo Hakusyo 2002). Although an estimation of the chloride transport between two basins was not treated in our model, chloride transport from the South Basin to the North Basin may be one of the possible mechanisms to maintain continuous increase of chloride ion concentration in the North Basin of the Lake Biwa.

\section{CONCLUSIONS}

Over 20 years trend of chloride ion concentration in the North Basin of Lake Biwa was reported. Its concentration level was lower than those in the so-called salt lakes, but the continuous increase of chloride ion concentration was statistically significant. On the basis of the conceptual model analysis and the several environmental data analysis, we discussed some possibilities that explain the increase of chloride concentration in
Lake Biwa. We suggested that the high concentrations of chloride ion in river water might be one of the major contributions to induce the increase. Precipitation is one of the dilution factors of the chloride in the surface lake water, but it may also promote the increase of loading from the non-point sources. We showed that the inflow from the non-point sources could be also major sources to induce the increase of chloride concentration. It is very difficult to monitor the loading from non-point sources continuously, but it is really important to measure the flux from the non-point sources running into Lake Biwa.

\section{REFERENCES}

Hori, T., Y. Sugiyama, M. Kanao, M. Nagai, N. Taniguchi, M. Sugiyama, T. Fujinaga. 1996. Distribution of some chemical components in Lake Biwa under usual and unusual wet and drought conditions, 1992-1995. Japanese Journal of Limnology, 57: 183-192.

Kankyo Hakusyo. Environmental White Paper, Shiga Prefecture.

Shigaken Kisyo Geppo. Monthly Weather Report Paper. Japan Weather Association.

Oonishi, Y. 1986. Land Use and Water Budget by River basins. In: Lake Biwa Research Institute (Ed.), Shiga Prefecture Regional Environment Atlas. Lake Biwa Research Institute.

Oonishi, Y. \& N. Imasato. 1974. A note on the water exchange between the South and the North Basins of Lake Biwa. Contributions, Geophysical Institute. Kyoto University, 14: 11-19.

Tanaka, Y. \& S. Ichiki. 1986. On the chemical components in the rain precipitated in Shiga. Rep. Shiga Pref. Inst. Pub. Hlth. \& Environ. Sci., 21: 156-159.

Williams, W.D. 2001. Anthropogenic salinisation of inland waters. Hydrobiologia, 466: 329-337.

Williams, W.D. \& N.V. Aladin. 1991. The Aral Sea - recent limnological changes and their conservation significance. Aquatic Conservation-Marine and Freshwater Ecosystems, 1: 3-23. 